\title{
Integrating RTI services in primary health care system: Observations from an operations research in Uttar Pradesh, India
}

\author{
M.E. Khan \\ Population Council \\ Saumya RamaRao \\ Population Council \\ R.B. Gupta \\ Bella C. Patel \\ Population Council \\ Leila Caleb-Varkey \\ Population Council
}

See next page for additional authors

Follow this and additional works at: https://knowledgecommons.popcouncil.org/departments_sbsr-rh

Part of the Community Health and Preventive Medicine Commons, International Public Health

Commons, Maternal and Child Health Commons, and the Women's Health Commons

How does access to this work benefit you? Let us know!

\section{Recommended Citation}

Khan, M.E., Saumya RamaRao, R.B. Gupta, Bella C. Patel, Leila Caleb-Varkey, Jayanti Tuladhar, Sanjeev Kumar, and John Townsend. 1997. "Integrating RTI services in primary health care system: Observations from an operations research in Uttar Pradesh, India," Asia and Near East OR/TA Project Special Report. New Delhi: Population Council. 


\section{Authors}

M.E. Khan, Saumya RamaRao, R.B. Gupta, Bella C. Patel, Leila Caleb-Varkey, Jayanti Tuladhar, Sanjeev Kumar, and John Townsend 


\section{INTEGRATING RTI SERVICES in Primary Health CARE SYSTEM}

Observations from an Operations

Research in Uttar Pradesh

\section{India}

M.E. Khan, Saumya RamaRao, R.B. Gupta, Bella Patel, Leila Caleb, Jayanti Tuladhar

Sanjeev Kumar, John W. Townsend

\section{Population Council}

\section{Asia \& Near East Operations Research and Technical Assistance Project New Delhi, India}

November 1997 


\title{
INTEGRATING RTI SERVICES IN Primary Health Care System Observations from an Operations Research in Uttar Pradesh
}

\author{
M.E. Khan, Saumya RamaRao, R.B. Gupta, Bella Patel, Leila Caleb, \\ Jayanti Tuladhar, Sanjeev Kumar and John W. Townsend ${ }^{1}$
}

\section{BACKGROUND}

Emerging evidences from community studies indicate that significant proportions of Indian women may have a reproductive tract infection (RTI). These are based on women's self reporting of symptoms and, clinical and laboratory examinations. For example, studies from four sites (urban slums of Bombay and Baroda, rural areas of West Bengal and Gujarat) found that women reported symptoms indicative of RTIs such as excessive discharge (22-57\%) backache (5 to 39\%) and lower abdominal pain (9 to 22\%) (BCC, CINI, Sewa-Rural and Streehitakarini, 1995). Similar studies carried out by Centre for Operations Research and Training (CORT) in various parts of the country including Bihar, Madhya Pradesh, Rajasthan, Gujarat and Delhi slums show that in all sites more than 40 per cent of the women had reported one or the other symptoms of RTI (Table 1).

Table 1: Percentage reporting gynaecological or RTI related problems

\begin{tabular}{lccl}
\hline States & $\begin{array}{c}\text { Percent reporting at } \\
\text { least one gyn. problem }\end{array}$ & $\begin{array}{c}\text { Average number of } \\
\text { problems reported }\end{array}$ & References \\
\hline Maharashtra & 92 & 3.6 & Bang \& Bang 1989 \\
Uttar Pradesh (one district) & 77 & 2.8 & PC, 1993 \\
Uttar Pradesh (two districts) & $61-70$ & 2.3 & CORT, 1997 \\
Madhya Pradesh (three districts) & $39-49$ & 1.2 & CORT, 1994 \\
Bihar (two districts) & $30-36$ & 1.5 & CORT, 1995 \\
Rajasthan (two districts) & $29-42$ & 1.5 & CORT, 1995 \\
\hline
\end{tabular}

Clinical examinations also revealed that cervicitis (8 to 40\%), vaginitis (10-15\%) and Pelvic Inflammatory Disease (1 to 17\%) were the prominent morbidities. Similarly, clinical and laboratory examinations of rural women in Karnataka revealed that 70 per cent had vaginitis, cervicitis or PID (Bhatia, et al., 1996). In terms of the specific infections, the laboratory assessment indicated bacterial vaginosis $(18.2 \%)$, candidiasis $(5.2 \%)$, trichomoniasis $(7.5 \%)$, chlamydia $(0.5 \%)$,

\footnotetext{
${ }^{1}$ The authors acknowledge with thanks the help extended by Dr. N.C. Bhargava of NACO and our colleague Dr. Christopher Elias, Population Council, Bangkok, in setting up this study and in organising various trainings.
} 
gonorrhoea $(0.8 \%)$, syphilis (1.5\%), and urinary tract infections (6.5\%). Apart from the community studies, clinical and microbiological studies have also confirmed the wide prevalence of RTIs among Indian women (Luthra, et al., 1992).

RTI prevalence in Uttar Pradesh (UP) appears to be of the order of 30 per cent as indicated by the preliminary results from the PERFORM survey conducted in UP. In particular, 23 per cent of the women who had recently given birth in Sitapur district, reported symptoms indicative of RTIs. A similar picture emerges from Agra district as well, where over 45 per cent of ever married women reported that they were currently suffering from excessive vaginal discharge (BSUP-Agra, 1995). To understand the magnitude of such levels of prevalence, the out patient records maintained at the Sidhauli Community Health Centre (CHC), a rural hospital in Sitapur district were examined. These records revealed that an estimated 20-30 per cent of women visiting the gynaecologists seek treatment at this health facility for ailments including profuse discharge, urinary tract infections, vaginitis, and PID. Given that women are in general asymptomatic and that even symptomatic women may not seek care the estimates presented here are the minimum levels of prevalence.

Most women do not seek treatment for RTIs for such reasons as lack of awareness, acceptance that RTIs are part of women's lives as well as lack of treatment facilities (Gittelsohn et al. 1994, Patel, et al. 1994, Bang and Bang, 1989). For example, the Agra baseline reported that just over a quarter of the women reporting gynaecological ailments had sought services. Of those who had not sought treatment, 50 per cent thought that the treatment would be expensive and over 40 per cent reported that they did not consider their condition serious enough to merit treatment. Similar observations have been made from other studies (CORT, 1997). For instance, in a recent survey in Delhi Slums, 70 percent women reported suffering from at least one symptom indicating gynaecological problem. Only 31 percent had sought treatment while the main reasons for not seeking treatment were 'did not feel it necessary' (34 percent) and poverty or treatment is expensive (18 percent).

On the supply side, in the public sector the treatment for RTIs is limited with most services provided through STD clinics in urban areas. Seeking treatment at STD clinics is stigmatizing to most clients, particularly so for women. Thus, most clients at STD clinics tend to be men and their partners may remain untreated. Women are more likely to seek treatment from gynaecologists or $\mathrm{MCH}$ care providers and do so for symptoms such as acute abdominal pain (reflective of PID), foul smelling and excessive discharge, and for conditions such as infertility and childlessness.

Interviews with ANMs in Agra district in Uttar Pradesh revealed that they are often approached by women for treatment of vaginal discharge. While most ANMs provided iron or calcium tablets as these were the only drugs available with them, some did provide metronidazole (Metrogyll) (Patel and Khan, 1997). Thus it is clear that while women bear the burden of direct and long term morbidity related to RTIs, they are less likely to seek or have access to treatment. This is supported by a number of studies which show that proportion of women patients treated at PHCs 
and other health facilities is significantly less than men. One of the important reasons for women's not seeking treatment at PHC, particularly for gynaecological problems is non-availability of lady doctor at the PHCs. Very few PHCs have women gynaecologist or even a qualified lady doctor. For these reasons, accessible and non-stigmatizing services must be available for women.

A recent review of the health sector by the World Bank recommended an essential package of reproductive and child health services to be included in the public sector programme (World Bank, 1995). One component of the package is the provision of RTI prevention and treatment services. The main strategies for management of RTIs include information health education, counselling, disease detection through screening, case findings and diagnosis by clinical and laboratory procedures, treatment of cases, and the management of sexual contacts (Pachauri, 1995). This package has been accepted by the Ministry of Health and Family Welfare, Government of India and it is an integral part of the recently announced Reproductive and Child Health $(\mathrm{RCH})$ program.

At present, even in clinics (public and private) providing RTI services, treatment of these infections is generally based on the symptoms reported by the patient and clinical examinations. As a result, patients are often prescribed wide spectrum drugs to treat a mix of infections which may lead to over treatment. Thus, diagnosis backed by laboratory support would enhance the quality of services.

Research on RTIs in India has so far concentrated on studies measuring prevalence of various infections, women's perceptions of them and their health seeking behaviour. Little is known about the service delivery aspects and the cost of service provision. For programme and policy purposes it is critical to have information on service delivery. Typically answers are sought for the feasibility of primary health care systems expanding to include prevention, diagnosis, and treatment programmes for RTIs and the need for resources within current structures (Ronald and Aral, 1992). Other issues raised pertain to the synergy between existing programmes and RTI services and whether the latter could strengthen the existing services and serve the interest of their clients.

The present paper discusses some preliminary observations from an ongoing Operations Research in Uttar Pradesh which attempts to answer the question on feasibility of integrating management of RTI with the existing primary health care services provided by primary health centres (PHCs) or rural health hospitals like Community Health Centres (CHC) and Post Partum Centres (PPC).

\section{The Public Health Clinics}

In the Indian context, rural public health facilities like Community Health Centres (CHCs), Post Partum Centres (PPCs) and Primary Health Centres (PHCs) are the lowest level which could diagnose and provide RTI services. These facilities have the requisite facilities in terms of personnel and infrastructure to provide RTI services, though CHCs and PPCs tend to be better endowed. 
ANMs at the subcentre, the smallest health facility in the public health sector, could educate community members about RTI, identify the cases and refer them to appropriate health facility for proper diagnosis and treatment.

CHCs have four doctors, one of whom is a female gynaecologist and who regularly conducts out patient clinics. Similarly, PPCs which are often attached to women hospitals, have at least one female gynaecologist to attend obstetric emergency cases as well as provide curative services at out patient clinics. The doctor at a PHC is generally a male physician. However, under a special program funded by USAID, implemented by SIFPSA ${ }^{2}$, private lady doctors are being contracted to provide gynaecological services on fixed days at selected PHCs. All the three types of health facilities have laboratories which are equipped to conduct blood, urine, malaria and TB sputum tests. Thus, it is possible to upgrade the available lab facilities and with the requisite training of the gynaecologist and the lab technician, RTI services can be provided.

\section{OBJECTIVES}

The specific objectives of the operations research are:

- To test feasibility of integrating case management of symptomatic women for RTIs at rural health clinics like CHC, PPCs and PHCs.

- To analyse the cost of providing RTI services at these levels.

- To describe the clients using the services and measure client satisfaction.

\section{Preparatory Work}

To implement the proposed OR, several important decisions were taken. It included:

- Selection of study sites.

- Approach for diagnosis and treatment of symptomatic women.

- Compatibility of the proposed approach to the national health program,

Study Sites: The study is being carried out at Sidhauli CHC and Mehmoodabad PPC in Sitapur district and Achhnera block PHC in Agra district of Uttar Pradesh. In these two districts, Population

\footnotetext{
${ }^{2}$ SIFPSA (State Innovation Family Planning Service Agency) is an autonomous agency established by the Uttar Pradesh Government to implement 250 million dollar IFPS Project, funded by USAID. IFPS aims to strenghten and improve access, quality and promotion of family planning in Uttar Pradesh, the most populous state of India with 156 million population in 1996.
} 
Council is assisting the district health authorities in their efforts to improve access, quality and promotion of the family welfare services. An attempt is being made to achieve this by implementing a pregnancy based approach for delivering ANC and PNC services, identifying couples with unmet need and providing services to them and strengthening supervision of the staff at all levels (see UPDATES 1, 2\&8).

The Sidhauli CHC offers various family welfare services such as immunization, antenatal checkups, family planning services, Medical Termination of Pregnancies, apart from general curative services, orthopaedic services, dental services and eye care. The Mehmoodabad PPC is a bigger facility geared to provide services to female clients. Apart from MCH and FP services including sterilizations, deliveries and MTPs, surgeries are also performed here. At both these centres, a working laboratory and a female doctor are present. The Sidhauli CHC clinic covers the Sidhauli block PHC area which has a population of 146,000 while the Mehmoodabad PPC covers the Khurwal block PHC area with a population of 143,000.

In Agra district, Achhnera PHC, has a laboratory and a lab technician in place. Though no lady doctor is posted at this PHC, a female private gynaecologist visits the PHC once a week on fixed days under the SIFPSA Visiting Doctor Scheme. She is conducting OPD on every Wednesday since November 1995 on a regular basis. The Achhnera block PHC area covers a population of 120,000 .

The Approach: As planned all symptomatic women seeking services are examined for RTIs and treated, if found to be infected with them. Services are provided at static out patient clinics in CHCs, PPCs and PHCs by the attending gynaecologist.

As planned in the proposal the syndromic approach of case management is being used to diagnose and treat vaginitis (inflammation of the vagina caused by bacterial vaginosis, candidiasis and trichomoniasis) and cervicitis (inflammation of the cervix usually caused by gonorrhoea or chlamydia), PID, urinary tract infections, and genital ulcer disease. To confirm the clinical findings of trichomoniasis, candidiasis and bacterial vaginosis, simple microscopy is used. The pathogens causing these three infections can be detected by inspecting wet mounts. The specimen slides are processed in the attached laboratory by the lab technician immediately and results are presented to the gynaecologist within a few minutes. These static clinic services is being offered on every gynaecological out patient clinic day.

All the block PHCs and the post partum centres have paramedical staff who are expected to provide out reach services to the communities. Apart from providing primary curative care, $\mathrm{MCH}$ and family planning services, they are also responsible for educating the community members about various preventive health measures. These paramedical staff could also be trained to educate the community members about RTI/STD, identify cases suffering from the disease (syndromic) and refer them to PHC/CHC/PPC for treatment. 
Compatibility with National Programs: While deciding to use syndromic approach of case management, it was fully appreciated that use of the syndromic approach alone for the detection of RTI may have poor predictive value (Bulut, et al., 1995, Younis et. al., 1993) and that the back up support provided by a laboratory doing simple tests (wet mount, gram staining) makes detection only slightly easier. However, as this approach for screening, diagnosis and treatment of RTI/STD cases is being implemented at the national level by the National AIDS Control Organization (NACO), Government of India, it was decided to follow the same guidelines. The NACO guidelines are essentially a syndromic approach with three different variations depending on the availability of speculums, microscopes, slides and lab facilities.

The syndromic charts which were finally developed for the study are given in Appendix 'A'.

\section{ACTivities}

For implementing the project several activities were undertaken. It included:

1. Upgradation of laboratories at the study site.

2. Training of doctors in syndromic management of RTI/STD.

\section{Upgradation of Laboratories}

Two factors were considered critical in upgradation of the existing laboratories at the selected health centres.

- Availability of essential equipments and reagents to carry out simple microscopic tests for RTI, and

- Availability of a trained lab technician to conduct the tests.

Most of the CHCs, PPCs and block PHCs in the rural areas are equipped with lab facility and a laboratory technician is posted there to carry out routine pathological tests, like blood, urine, malaria and TB sputum tests. The equipment and supplies to conduct these tests are generally available.

The existing laboratory can undertake simple microscopy procedures to diagnose the presence of some RTIs. RTIs such as trichomoniasis, candidiasis and bacterial vaginosis can be detected with the help of saline wet mounts. Wet mount scrutiny can reveal the organism causing these infections. Other infections such as syphilis and gonorrhoea though easy to test require a different set of procedures which involve equipment and reagents not currently available in PHCs, $\mathrm{CHCs}$ and PP Centres. In addition, laboratory testing for infections such as chlamydia are expensive 
and not available even in most private sector hospitals. Thus, for the present study, it was felt that with the present set-up of health facilities, back-up laboratory support for diagnosis would be realistic only for trichomoniasis, candidiasis and bacterial vaginosis.

Situation Analysis of Laboratory Facilities: A quick situation analysis of the laboratory facilities at the study sites revealed that most of the essential equipments such as microscope (with light source), centrifuge machine (manual) and burner lamps were available except a few items like hot air oven (to sterilize glass ware). Apart from this, most of the sites did not have specimen collection swabs, bacteriology loop and recurring supplies such as slides, cover slips, test tubes, syringes and needles, and reagents were generally short supplied. Thus, it was estimated that with a small investment in essential supplies, the laboratory will be sufficiently equipped to provide the specified tests. Accordingly, in the project a small amount of money was allocated for providing the required supplies.

Training of Lab. Technicians: At all the three study sites, lab technicians were in position. The laboratory technicians are trained persons with a one year Diploma in Medical Laboratory Technique. However, during the situation analysis, all of them expressed need of reorientation training for the diagnosis of the pathogens causing the RTI infections as presently, they were not doing these tests.

After considerable discussion with the experts, microbiologists, NACO technical officials and Population Council professionals who have wide experience in conducting such operations research, a ten day training program was developed and organized at the Department of Microbiology, KG Medical College, Lucknow.

Considering the importance of upscaling the experiment and the fact that in phased manner, this approach will be extended to all the block PHCs and rural hospitals by NACO, the lab training was extended to all the lab technicians attached with PHCs/CHCs, falling under the area covered by OR project in Sitapur and Agra districts. Altogether 10 lab. technicians participated in the training. They were given both technical and practical training in various laboratory testing techniques. Practical training was given much more emphasis than theoretical part. The course contents through which they passed through is given in Appendix 'B'. Broadly, it consisted of diagnostic techniques for several infections including candidiasis, trichomoniasis, bacterial vaginosis, gonorrhoea, chlamydia, syphilis, etc., sterilization of glassware, maintenance of equipments, quality control to registration and record keeping. 


\section{Training of Doctors}

Currently patients infected with RTIs are diagnosed and treated on the basis of symptoms or syndromes they report. However, it is difficult to make a clinical diagnosis as different pathogens can cause the same syndrome or when there is more than one infection. In order to aid diagnosis the syndromic approach is advocated which is a combined treatment for all pathogens commonly found to cause a syndrome. This approach uses a combination of methods such as flow charts for case management decisions, risk assessments, clinical examinations, education and counselling, and partner management to diagnose and treat RTI clients. To train the doctors, NACO in collaboration with WHO experts have developed guidelines and training modules for the management of STDs (NACO, 1994). NACO is using these manuals and guidelines to conduct training workshops for doctors and laboratory technicians all over the country. The training comprises of six modules covering the following topics:

Module 1 deals with the transmission of STDs, the biological and social factors influencing transmission, their epidemiology, social and behavioural impact, and control.

Module 2 outlines the problems of etiological approach to STD case management, and introduces the syndromic approach as an alternative. It also introduces the use of flow charts for the syndromic management of clients.

Module 3 is about history taking and examination of patients.

Module 4 is a step-by-step guide of the flow charts to arrive at an accurate diagnosis, provide the correct drug therapy and dosage for each diagnosis, and counsel the patient. NACO has developed seven different flow charts on urethral discharge, genital ulcers, vaginal discharge, lower abdominal pain, scrotal swelling, inguinal bubo and neonatal conjunctivitis. Some of these flow charts also have the option of using speculums and microscopes, if available.

Module 5 is about the education and counselling aspects of treatment.

Module 6 describes the approaches to partner management.

To keep the training similar to what MOH\&FW is implementing in the country through National STD/AIDS Control programs, it was decided to use the guidelines and manuals developed by NACO. A four day training workshop was organized at Lucknow in collaboration with NACO, KG Medical College and State Institute of Health and Family Welfare (SIHFW). While theoretical training was organized at SIHFW, practical training was given at Department of Ob/Gyn. Department of Microbiology helped in setting up facility for microscopic examination of the slides 
by the trainees at the Ob/Gyn. unit itself. This saved considerable amount of time from transporting trainees from one department to the other and made the practice easier and better supervised. A number of experts from other parts of the country having experience in conducting such trainings and similar OR in rural settings were invited as guest faculties. Technical experts from NACO were present through out the training and acted as key resource persons. Use of the flow charts for the diagnosis of diseases which were developed in consultation with NACO (see Appendix 'A') were shared and discussed extensively during the training. The details of the training program which was followed in the workshop is given in Appendix ' $\mathrm{C}$ '.

Altogether 15 doctors and two tutors of ANM Training Centres (one each from Agra and Sitapur) participated in the training workshop. As in the case of lab technicians training, apart from the gynaecologist of the three study sites, doctors posted at Block PHCs of OR project area and the Dy. CMO responsible for coordinating the OR projects at the district level also participated in the training.

A comparison of the results of pre and post training tests revealed considerable improvement in the understanding and knowledge of participants, both about syndromic approach, RTI and its management (see Tables 2 and 3).

Table 2: Gain in Knowledge about RTI and Syndromic Approach

\begin{tabular}{lccc}
\hline & $\begin{array}{c}\text { Pre } \\
\text { training }\end{array}$ & $\begin{array}{c}\text { Post } \\
\text { training }\end{array}$ & $\begin{array}{c}\text { Test of signi- } \\
\text { ficance (t test) }\end{array}$ \\
\hline $\begin{array}{l}\text { Average number of common RTI/STD diseases } \\
\text { mentioned as prevalent in the work area of } \\
\text { participants }\end{array}$ & 2.1 & 3.6 & $\mathrm{p}<.05$ \\
$\begin{array}{l}\text { Main features of syndromic approach mentioned } \\
\text { Average number of factors mentioned that may } \\
\text { encourage the onset of infection or disease in the }\end{array}$ & 2.2 & 3.5 & $\mathrm{p}<.05$ \\
$\begin{array}{l}\text { female reproductive system } \\
\text { Average number of measures mentioned which } \\
\text { could reduce chances of infection by STD }\end{array}$ & 1.2 & 2.9 & $\mathrm{NS}$ \\
$\begin{array}{l}\text { Average number of STDs (Chancroid and } \\
\text { Herpes) mentioned that can cause genital lesions }\end{array}$ & 0.6 & 1.7 & $\mathrm{NS}$ \\
NS = Not Significant & & 1.4 & $\mathrm{p}<.05$ \\
\end{tabular}


Table 3: Increase in Knowledge about RTI during pre and post training test

\begin{tabular}{|c|c|c|c|}
\hline Percent mentioning that & $\begin{array}{c}\text { Pre } \\
\text { training }\end{array}$ & $\begin{array}{l}\text { Post } \\
\text { training }\end{array}$ & $\begin{array}{c}\text { Test of } \\
\text { proportion }\end{array}$ \\
\hline Syndromic approach is scientific & 40.0 & 70.6 & * \\
\hline $\begin{array}{l}\text { It is better to treat each patient for all the possible causes } \\
\text { simultaneously }\end{array}$ & 26.7 & 64.7 & $* *$ \\
\hline $\begin{array}{l}\text { A female client who has a thick, curd-like white vaginal } \\
\text { discharge, itching and soreness is most likely to have } \\
\text { Moniliasis }\end{array}$ & 46.7 & 58.8 & NS \\
\hline Cervical cancer is related to STD & 66.7 & 47.1 & $*$ \\
\hline $\begin{array}{l}\text { Pelvic inflammatory disease (PID) is a severe infection of } \\
\text { the uterus and Fallopian tube }\end{array}$ & 80.0 & 88.2 & NS \\
\hline STDs are most common in the age group of $15-30$ years & 73.3 & 88.2 & NS \\
\hline Uncircumcised men are more susceptible to STD infection & 73.3 & 94.1 & $*$ \\
\hline PID increases the risk of ectopic pregnancy by $7-10$ folds & 6.7 & 29.4 & $*$ \\
\hline $\begin{array}{l}\text { Correctly describing normal vaginal discharge giving } \\
\text { colour and consistency changes over a monthly cycle }\end{array}$ & 26.7 & 88.2 & $* *$ \\
\hline $\begin{array}{l}\text { Correctly aware of reasons for females being more } \\
\text { susceptible to sexually transmitted disease }\end{array}$ & 13.3 & 82.4 & $* *$ \\
\hline Number of trainee participants & 15 & 17 & \\
\hline
\end{tabular}

\section{Preliminary Findings}

Currently preliminary data from two sites are available - one from PPC Mehmoodabad and the other from Achhnera PHC, Agra. As the two health facilities are quite different in its nature and functioning, the results are discussed separately.

PPC Mehmoodabad: PPC Mehmoodabad being a relatively big health facility and attached to women hospital, the turnover of female patients are quite large. The average number of outdoor patients is around 917 per month (range 825-1029), giving a daily workload of 36-40 patients.

During April-Sept. 1997, a total of 5241 women attended OPD. Its distribution by broad categories of problems are presented in Table 4. 
Table 4: Distribution of OPD Patients by Type of Problem at the Mehmoodabad PPCs during April to September 1997

\begin{tabular}{lrr}
\hline Problems/diseases & Number of women & Percentage \\
\hline Gynaecological problems & 1506 & 28.8 \\
Obstetric problems & 2043 & 39.0 \\
Abortion & 78 & 1.5 \\
RTI & 278 & 5.3 \\
FP & 217 & 4.1 \\
Other diseases & 1119 & 21.3 \\
\hline Total & 5241 & 100.0 \\
\hline
\end{tabular}

The figures in Table 5 shows, out of the total 5241 women who sought treatment at the PPC during April - Sept. 1997, only 278 (5.3 per cent) had complained for some RTI problems. According to service statistics, out of these 278 suspected cases of RTI, 235 (84 per cent) were subjected to laboratory tests. Most of the time, only wet mount tests were performed as because of the nonavailability of stains, gram stain test was not possible. The results of the lab. tests are summarised in Table 5.

Table 5: Results of Laboratory Tests of Suspected RTI Cases

\begin{tabular}{|c|c|c|c|c|c|}
\hline \multirow[t]{4}{*}{ Total RTI cases } & \multirow{4}{*}{$\begin{array}{l}\text { No. of lab tests } \\
\text { done }\end{array}$} & \multicolumn{4}{|c|}{ Type of tests } \\
\hline & & \multicolumn{2}{|c|}{ Wet mount } & \multicolumn{2}{|c|}{ Gram staining } \\
\hline & & \multicolumn{2}{|c|}{ Results } & \multicolumn{2}{|c|}{ Results } \\
\hline & & $+\mathrm{ve}$ & $-v e$ & $+\mathrm{ve}$ & -ve \\
\hline 271 & 235 & $\begin{array}{l}2 \mathrm{CA} \\
2 \mathrm{GV} / \mathrm{CC} \\
5 \mathrm{CC}\end{array}$ & 226 & $\begin{array}{l}2 \mathrm{GV} / \mathrm{CC} \\
3 \mathrm{CC}\end{array}$ & 46 \\
\hline
\end{tabular}

CA = Candida-albicans; Gv = Gardinella Vaginitis; $\mathrm{CC}=$ Clue-cells.

As the table shows, out of the 235 cases for which lab test was done, only in 14 cases (5.9 per cent), the results were positive. Out of these, 2 were diagnosed for candidiasis, 4 for Gardinella while the remaining 8 were cases of Clue-cells indicative of bacterial vaginosis.

A discussion with the gynaecologist posted at the PPC revealed that the lab. technicians did not face any problem in performing the tests and their results, as checked by the doctor herself, were quite reliable.

Generally the RTI patients were prescribed Norflaxin, Tinidazol and Metronidazole for 7 days. If symptoms persisted, they were provided with any one of the following antibiotic Tetra Cycline, Doxy- 
cycline, Ampi-cycline, Amoxi-cycline and Nor-flaxin, Tinidazol and Metronidazole or Injection Placentrex for 10 days. These medicines were given with Anti-inflammatory and pain killer ibuprofen, paracetamol, Dielonee Sodium. As and when these medicines were not in stock, the patients were asked to purchase from the market and show it to the doctor before its use. According to the doctor at PPC all the patients purchased the drugs.

\section{Achhnera PHC:}

In block PHC Achhnera, under SIFPSA's scheme a lady private gynaecologist has been visiting the PHC village regularly on every Wednesday and organises OPD clinic for women patients. The scheme is showing quite encouraging results. A total of 2873 clients have been served in 88 clinics conducted so far starting from November 1995. Without any propaganda or formal publicity, just by word of mouth, the turnover of women per clinic day was on an average about 33 women.

Table 6 gives the number of patients by their type of problems who were examined and treated in the OPD organised under SIFPSA scheme. Sixty percent of the clients were obstetric cases, followed by 22 percent gynaec cases, 14 percent RTI cases, 2 percent for family planning advices, services or followup and 10 percent with other general problems.

\section{Table 6: Number of patients by type of problems served by SIFPSA doctor during Nov.95 - Oct.97 (88 clinic days)}

\begin{tabular}{lcc}
\hline Problems* & Number of women & Percentage \\
\hline Gynaecological & 637 & 22.2 \\
Obstetric & 1722 & 59.9 \\
RTI & 401 & 14.0 \\
FP & 59 & 2.1 \\
Others & 299 & 10.3 \\
\hline All & 2873 & 100.0 \\
\hline *Percentage adds to more than 100 due to multiple problems reported. &
\end{tabular}

Out of the 1722 obstetric cases, 40 percent were for normal antenatal check-up, 17 percent for pregnancy with high risk factors, anaemia or pain, 3.6 percent with full term pregnancy or with loss of foetal movement and 10 percent with lactational ameanorrhoea or suspected pregnancy. Nine percent of the obstetric cases had come for abortion services while 3.5 percent $(n=61)$ with incomplete abortion or other complications following abortion.

Women who sought treatment for gynaec problem mainly reported bleeding problems, infertility (primary or secondary), UTI, prolapse or menopausal complaints (Appendix D).

Out of the 401 RTI patients, 45 percent (6 percent of the total cases) were suffering from Pelvic Inflammatory Disease, and 44 percent from leucorrhoea, while others (ranging from 1 to 2.5 percent) 
complained of vaginal discharge, chronic or acute cervicitis, lower abdominal pain, trichoma, trichomoniasis and candidiasis (Table 7).

Table 7: Distribution of RTI patients

\begin{tabular}{lccc}
\hline Symptoms & Number & Percent* $^{*}$ & Percent $^{* *}$ \\
\hline Pelvic inflammatory disease & 179 & 6.3 & 44.6 \\
Leucorrhoea & 175 & 6.1 & 43.6 \\
Vaginal discharge & 10 & 0.3 & 2.5 \\
Chronic or acute cervicitis & 10 & 0.3 & 2.5 \\
Lower abdominal pain & 12 & 0.4 & 3.0 \\
Trichoma & 3 & 0.1 & 0.8 \\
Trichomoniasis & 9 & 0.3 & 2.2 \\
Candidiasis & 3 & 0.1 & 0.8 \\
\hline All & 401 & 7.8 & 100 \\
\hline
\end{tabular}

* Based on all types of patients served by SIFPSA doctor (i.e. base is 2873)

**Taking RTI patients as base (i.e., 401)

80-90 percent of the women are given treatment on the basis of symptoms. In few cases, the women are referred to Agra Government Women's Hospital or asked to undergo pathological tests.

Since July 1997, laboratory test facilities at the PHCs are being utilised to test suspected cases of RTI. According to service statistics since July 1997, out of the 100 suspected cases of RTI at Achhnera, only 18 were subjected to laboratory tests. Most of the time only Pap smear is done. There are some administrative problems in using the lab. facilities effectively. Efforts are being made to overcome these hindrances.

Generally, the RTI patients were prescribed Crystalline Vaginal tablet, Tinidazol, Doxycycline, Evalon (Estriol) cream. These medicines were given with anti-inflammatory. However, condoms were given to only 3 women with RTI and in three cases both the partners were treated.

Majority (82 percent) of the RTI cases were asked to come for follow-up check-up after 15 days and 5 percent after a month.

The regular turnover of women ranging from 14 to 57 per clinic day shows an existing unmet need for reproductive health services. While there are 24 to 30 women treated at PHC by male doctor and 50 to 180 by ANM/LHV every month in approximately 20 clinic days, the lady gynaecologist serve 80 to 190 cases every month in 4 clinic days. This pave a way to meet the demand of the clients by bringing in private gynaecologist or lady doctor even once in a week regularly. Such operations research help to identify the gaps and to introduce and strengthen reproductive health services in the existing system in the most appropriate and cost effective way.

\section{Increased Utilisation of PHCs}


An attempt has been made to assess whether the patients who are treated by the lady doctors at Achhnera PHC are the same who otherwise would have been attended by ANM/LHV on the MCH clinic day at PHCs. An analysis of the time series data of the number of women served at the MCH clinics at PHC for the last 10 months shows that:

1. Number of women coming at the MCH clinics organised by ANM/LHV at the PHC on Tuesday has progressively increased from 51 to 208 per month. In other words, women have not shifted from ANM/LHV MCH clinic to OPD organised by lady doctors, just because the latter was more qualified. ANM/LHV, however, are referring complicated cases to the lady doctors' clinic on Wednesday.

2. The two clinics (one each organised by ANM/LHV and lady doctor) taken together are providing a package of reproductive health services as envisaged by $\mathrm{RCH}$ programme. With ANM providing registeration of pregnant women, iron folic acid and tetnus toxoid.

3. Availability of these services, has increased the utility of the PHC and now number of the women utilising the PHC is considerably more than before introduction of SIFPSA Scheme for addressing to the women's RTI/RH needs. A cost analysis is in progress and relevant information is being collected to analyse economic feasibility of integrating RTI and other reproductive health services in the existing facilities of PHC.

\section{LESSONS LEARNED}

An analysis of the processes involved in implementation of the projects and preliminary findings from the three sites suggest several important points. It includes:

- Most of the CHCs, PPCs and block PHCs have lab facilities which with a marginal resource input could be made functional for confirming the clinical findings of trichomoniasis, candidiasis and bacterial vaginosis.

- In most of these clinics, reagent to perform these tests (wet mount and Gram Staining) are not available and hence its regular supply is critical to keep these laboratories functional.

- Generally the lab technicians are eager and capable to carry out these tests. A 3-5 day reorientation of lab technicians as recommended by NACO will be perhaps sufficient. A rigorous 10 days training given under present study is not required. Instead a practical reorientation after 4 months may be useful. Alternatively, on the spot checking of the lab. technicians findings as done at Mehmodabad PP centre by the lady doctor herself, also could help in maintaining a good standard of diagnosis. 
The guidelines and manuals developed by the NACO are effective and the present study shows that a 4 days training is effective in imparting knowledge about syndromic approach for the diagnosis and management of RTI to gynaecologists already treating clients with infections.

- Administrative delay in procuring the reagents and frequent transfer/absence of gynaecologist posted at the health facilities (in the present case $\mathrm{CHC}$ at Sidhauli) are some of the serious bottlenecks in effective implementation of the project. For instance, despite the fact that money was provided under the project to purchase reagents, it took almost 4 months before it was procured and supplied to clinics. If after training the lab technicians do not get opportunity to use their new acquired skill for long time, chance of losing the benefits of training is quite high.

Similarly at CHC Sidhauli, the gynaecologist who was trained under the project was transferred soon after training. The lady doctor who replaced her went on long leave and the present doctor who is posted for attending Gyn. clinic at the $\mathrm{CHC}$ is an experienced ophthalmologist and has not received the training. Such administrative difficulties could easily frustrate the initiatives taken for providing $\mathrm{RH}$ package at these health facilities.

Among the three types of health facilities which are being used for the present operations research, the PPCs seems to be the most appropriate one for such intervention. As generally, PPCs are attached to women hospital, a much larger number of women avail its services. Consequently, chances of getting RTI cases, frequency of using lab facilities are also significantly more. A discussion with the lab technician at PPC revealed that they were quite happy with this added responsibility, i.e. testing for RTI cases. As they were regularly doing these tests, it has become a normal task and their diagnosis as certified by the doctor were quite correct.

- In contrast to this at the Sidhauli CHCs frequent transfer/absence of lady doctor or posting of a senior eye specialist (ophthalmologist) at $\mathrm{MCH}$ clinic could not generate enough cases for lab testing nor the women could receive proper treatment. This is evident from the fact that only 5 cases in April and 7 cases in September were sent for lab testing. A lady doctor who was visiting the CHC under SIFPSA scheme instead of recommending the suspected RTI patients to go through the lab. tests, often diverted them to her own private clinic at Sidhauli or Lucknow. Since September, she has been shifted to another PHC (Kamlapur) as the doctor on leave reported back. Such administrative weaknesses could contribute significantly in continued under-utilization of public health facilities.

At PHCs where only male doctors are posted does not create enough demand for the PHC services by women suffering from RTI or any other major reproductive health problems demanding internal examination. Generally they go to nearby towns (in this case to Agra) for treatment. However, as in case of Achhnera, PHC where a private 
female gynaecologist has been hired to visit the clinic for 3-4 hours once in a week, on an average 30 women (ranging between 20-35 per clinic day) come to avail the services. An analysis of the patient's problems revealed that 5.5 per cent were suspected cases of RTI. However, all of them were not provided a needed laboratory test. Certain logistic problems like who will take the specimen swabs from the patients and deliver to laboratory (as no ANM is attached to OPD) and occasional non-availability of laboratory technician reinforce lady doctor general habit to prescribe treatment mainly on stated symptoms and/or clinical examination.

- Both at Mehmoodabad and Achhnera, often the medicines for the treatment of RTI patients (in fact most of the patients with reproductive health problems) are in short supply. Hence in majority of the cases, particularly at Achhnera, the patients are prescribed medicines to purchase from the market. The study shows that generally the patients did not object to it and purchased the medicines. It indicates that

(a) if a lady doctor is made available at the health centres even for one day in a week, it will go a long way in increasing accessibility of reproductive health services to women.

(b) patients are ready for paying for their health care, at least for purchase of drugs.

(c) Observations from Achhnera PHC shows that such an intervention also increases the demand of PHC services. According to the study, utilisation of $\mathrm{MCH}$ clinics organised by ANM/LHV at PHC doubled within a year.

\section{References}

Bang, R.A., Bang A.T., Baitule, M., Chaudhury, Y., Sarmukaddam, S., and Tale, O. 1989. "High Prevalence of Gynaecological Diseases in Rural Indian Women." The Lancet, January 14, 1989.

BCC, CINI, SEWA-Rural and Streehitakarini. 1995. "Prevalence of clinically detectable gynaecological morbidity in India: Results of four community based studies." Report presented to the Ford Foundation, New Delhi.

Bhatia, Jagdish, John Cleland, Leela Bhagvan and N. S. N. Rao. 1996. "Prevalence of gynaecological morbidity among women in South India." Report presented to the Ford Foundation, New Delhi.

BSUP-Agra. 1995. District Level Baseline Survey of Family Planning Program in Uttar Pradesh. The Population Council and Mode Research Pvt. Ltd.

Bulut, Aysen, Nuray Yolsal, Veronique Fillipi and Wendy Graham. 1995. "In search of truth: Comparing alternative sources of information on Reproductive Tract Infection," Reproductive Health Matters. 
CORT 1997. Knowledge, Attitude, Behaviour and Practice of the Community on STD/HIV in Slums of Delhi - A Study of Govindpuri Slum, New Delhi. Monograph.

CORT 1997. Attitude towards Male and Female Sterilization in Almora and Gorakhpur Districts of Uttar Pradesh. Monograph.

Gittelsohn, J., Bentley, M.E., Pelto, P.J., Nag, M., Pachauri, S., Harrison, A.D., and Landman, L.T. 1994. Listening to Women Talk about their Health: Issues and Evidence from India. Har-Anand Publications, New Delhi.

Luthra, Usha K., Suman Mehta, N. C. Bhargava, Prema Ramachandran, N. S. Murthy, A. Sehgal and B. N. Saxena. 1992. "Reproductive tract infections in India: The need for comprehensive reproductive health policy and programs" in Adrienne Germain, King K. Holmes, Peter Piot and Judith N. Wasserheit (edited) Reproductive Tract Infections: Global Impact and Priorities for Women's Reproductive Health. Plenum Press: New York.

National Aids Control Organization. 1994. Reference Manual for Laboratory Workers: Diagnosis of Sexually Transmitted Diseases. NACO: New Delhi.

National Aids Control Organization in collaboration with WHO. Management of STD Patients. Training Modules No. 1 to 6. NACO: New Delhi.

Pachauri, Saroj. 1995. Defining a Reproductive Health Package for India: A Proposed Framework. Regional Working Papers, No. 4. The Population Council: New Delhi.

Patel, B.C., Barge, S., Kolhe, R., and Sadhwani, H. 1994. Listening to Women Talk about their Reproductive Health Problems in the Urban Slums and Rural Areas of Baroda.

Patel, B.C. and Khan, M.E. 1997. Women's Reproductive Health Problems in Rural Uttar Pradesh: Observations from a Community Survey. Submitted to Social Change for publication in Special Issue on Reproductive Health.

Ronald, Allan and Sevgi O. Aral. 1992. "Assessment and prioritization of actions to prevent and control reproductive tract infections in the third world," in Reproductive Tract Infections: Global Impact and Priorities for Women's Reproductive Health. Plenum Press: New York.

UPDATE Number 1. 1996. Operations Research in Sitapur and Agra Districts Uttar Pradesh. Asia and Near East Operations Research and Technical Assistance, Population Council, New Delhi, 14th May.

UPDATE Number 2. 1996. Using Clients' Oriented Alternatives to Improve Family Planning Services. Asia and Near East Operations Research and Technical Assistance, Population Council, New Delhi, 30th September.

World Bank 1995. India's Family Welfare Program: Toward a Reproductive and child Health Approach. Report No.14644-IN. Population and Human Resources Operations Division, South Asia Country Department II (Bhutan, India, Nepal). June 23. 
Younis, N., H. Khattab, H. Zurayk, M. El-Mouelhy, M Fadle Amin and A.M. Farag. 1993. "A community study of gynaecological and related morbidities in rural Egypt," Studies in Family Planning, Vol. 24(3): 175-186. 
Appendix A 


\section{Programme Schedule for Training of Lab Technician}

\section{Topic \\ Tea \\ Demonstration \\ Lunch \\ Practicals}

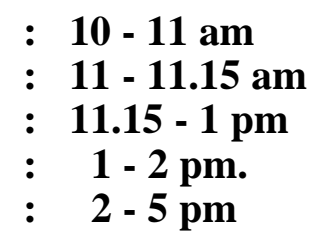

\begin{tabular}{|c|c|c|c|}
\hline Date & Topic & Demonstration & Practicals \\
\hline Nov 26, 1996 & $\begin{array}{l}\text { 1. Introduction to RTIs } \\
\text { 2. Pre evaluation test } \\
\text { 3. Procedures for hospital } \\
\text { infection control }\end{array}$ & $\begin{array}{l}\text { 1. Methods } \\
\text { 2. How to stain } \\
\text { 3. Collection of samples } \\
\text { 4. How to store samples } \\
\text { 5. How to transport samples } \\
\text { 6. Different types of } \\
\text { specimens }(M+F)\end{array}$ & $\begin{array}{l}\text { 1. Equipment maintenance } \\
\text { and cleaning procedures }\end{array}$ \\
\hline Nov 27, 1996 & $\begin{array}{l}\text { Overview of RTIs including } \\
\text { rare ones }\end{array}$ & $\begin{array}{l}\text { 1. Smear preparation } \\
\text { 2. Staining } \\
\text { 3. Examination of unstained } \\
\text { smears }\end{array}$ & $\begin{array}{l}\text { 1. Smear preparation } \\
\text { 2. Staining } \\
\text { 3. Examination of } \\
\text { unstained smears }\end{array}$ \\
\hline Nov 28, 1996 & $\begin{array}{l}\text { 1. Lab diagnosis of RTIs } \\
\text { 2. Procedures of lab } \\
\text { diagnosis }\end{array}$ & $\begin{array}{l}\text { 1. Bacterial media } \\
\text { 2. Preparation } \\
\text { 3. Quantification }\end{array}$ & $\begin{array}{l}\text { 1. Gram staining } \\
\text { 2. KOH preparation } \\
\text { 3. Litmus paper } \\
\text { examination } \\
\text { 4. Amine test }\end{array}$ \\
\hline Nov 30, 1996 & Urinary Tract Infections & $\begin{array}{l}\text { 1. Urine collection } \\
\text { 2. Chemical and microscopic } \\
\text { examination } \\
\text { 3. Culture procedure }\end{array}$ & $\begin{array}{l}\text { 1. Exam of urine } \\
\text { 2. Sugar, albumin and } \\
\text { protein } \\
\text { 3. Microscopic exam of } \\
\text { urine sediment } \\
\text { 4. Gram staining of urine } \\
\text { sediment }\end{array}$ \\
\hline Dec 2, 1996 & $\begin{array}{l}\text { 1. Genital Ulcer Disease } \\
\text { 2. Syphilis } \\
\text { 3. Chancroid } \\
\text { 4. LGV } \\
\text { 5. Venereum Granuloma } \\
\text { 6. Donovanosis }\end{array}$ & $\begin{array}{l}\text { 1. Specimen collection } \\
\text { 2. Organisms } \\
\text { 3. Demonstration of VDRL, } \\
\text { RPR } \\
\text { 4. Staining }\end{array}$ & $\begin{array}{l}\text { 1. Specimen collection } \\
\text { 2. Making smears } \\
\text { 3. Staining smears }\end{array}$ \\
\hline Dec 3, 1996 & $\begin{array}{l}\text { Description of gonorrhoea } \\
\text { and non-gonoccocal } \\
\text { urethiritis }\end{array}$ & $\begin{array}{l}\text { 1. Specimen collection } \\
\text { 2. Organisms } \\
\text { 3. Staining }\end{array}$ & $\begin{array}{l}\text { 1. Specimen collection } \\
\text { 2. Making smears } \\
\text { 3. Staining smears }\end{array}$ \\
\hline Dec 4, 1996 & $\begin{array}{l}\text { Vaginitis } \\
\text { Trichomoniasis } \\
\text { Candidiasis } \\
\text { Bacterial Vaginosis }\end{array}$ & $\begin{array}{l}\text { 1. Urine and vaginal culture } \\
\text { 2. Collection and processing } \\
\text { 3. Demonstration of causative } \\
\text { organisms } \\
\text { 4. Culture and stain } \\
\text { proccedures }\end{array}$ & $\begin{array}{l}\text { 1. Litmus Test } \\
\text { 2. Amine test } \\
\text { 3. Trichomoniasis wet } \\
\text { smear } \\
\text { 4. Candiasis staining } \\
\text { 5. Clue cells for BV }\end{array}$ \\
\hline Dec 6, 1996 & $\begin{array}{l}\text { 1. Herpes Simplex } \\
\text { 2. Post evaluation test }\end{array}$ & $\begin{array}{l}\text { Demonstration of Herpes } \\
\text { Simplex }\end{array}$ & $\begin{array}{l}\text { 1. Litmus Test } \\
\text { 2. Amine test } \\
\text { 3. Trichomoniasis wet } \\
\text { smear } \\
\text { 4. Candiasis staining } \\
\text { 5. Clue cells for BV }\end{array}$ \\
\hline
\end{tabular}




\section{Programme Schedule for Training of Doctors}

\begin{tabular}{|l|l|}
\hline December 10,1996 & Welcome Address \\
\hline $9.30-10.30 \mathrm{am}$ & $\begin{array}{l}\text { Purpose of the meeting } \\
\text { Speakers }\end{array}$ \\
\hline & Inaugural address \\
\hline $10.30-11.00 \mathrm{am}$. & Tea break \\
\hline $11.00-11.15 \mathrm{am}$. & Pre-training KAP of RTI Case Management \\
\hline & Chaiperson \\
\hline $11.15-1.00 \mathrm{pm}$. & $\begin{array}{l}\text { Situation of RTI in UP } \\
\text { RTI Case Management - Field experience from Bundi disitrict }\end{array}$ \\
\hline $1.00-1.45 \mathrm{pm}$. & Lelationship between RTIs, STDs and AIDS \\
\hline & Chairperson \\
\hline $1.45-2.30 \mathrm{pm}$. & Women's gynaecological problems and treatment \\
\hline $2.30-3.15 \mathrm{pm}$. & Epidemiological profileof RTIs \\
\hline $3.15-4.00 \mathrm{pm}$. & Syndromic approach \\
\hline $4.00-4.30 \mathrm{pm}$. & Open session \\
\hline December 11, 1996 & Chairperson \\
\hline $9.30-10.10 \mathrm{am}$ & Endogneous and iatrogenic infections \\
\hline $10.10-10.50 \mathrm{am}$. & Urethral and vaginal discharge \\
\hline $10.50-11.00 \mathrm{am}$. & Tenorrhoea \\
\hline $11.00-12.00 \mathrm{noon}$ & Module 1 - Working groups (6 persons partiicpated \\
\hline $12.00-1.00 \mathrm{pm}$. & Presentation of working group discussions \\
\hline $1.00-2.00 \mathrm{pm}$. & Lunch \\
\hline $2.00-3.45 \mathrm{pm}$. & Modules 2 \& 3 - Working Groups (5 persons participated) \\
\hline $3.45-4.00 \mathrm{pm}$. & Tea \\
\hline $4.00-5.00 \mathrm{pm}$. & Presentation of Working Group discussions \\
\hline $5.00-5.30 \mathrm{pm}$. & Open session \\
\hline December 12,1996 & Chairperson \\
\hline
\end{tabular}




\begin{tabular}{|l|l|}
\hline $9.30-10.30 \mathrm{am}$ & $\begin{array}{l}\text { Genital Ulcer disease: } \\
\text { Syphillis } \\
\text { Chancroid } \\
\text { Herpes }\end{array}$ \\
\hline $10.30-10.45 \mathrm{am}$. & Tea break \\
\hline $10.45-12.00 \mathrm{noon}$ & Examination of patients \\
\hline $12.00-1.30 \mathrm{pm}$. & Visit to Microbiology Laboratory \\
\hline $1.30-2.15 \mathrm{pm}$. & Lunch \\
\hline $2.15-4.00 \mathrm{pm}$. & Modules 4 and 5: Working Groups \\
\hline $4.00-4.15 \mathrm{pm}$. & Tea \\
\hline $4.15-5.30 \mathrm{pm}$. & Presentation of Working Group discussions \\
\hline December 11, 1996 & Examination of Patients \\
\hline $10.00-11.30 \mathrm{am}$. & Chairperson \\
\hline $11.30-12.15 \mathrm{pm}$. & Module 6 - Working groups (4 persons partiicpated \\
\hline $12.15-1.15 \mathrm{p} . \mathrm{m}$. & Lunch \\
\hline $1.15-2.00 \mathrm{pm}$. & Presentation of Working Group Discussions \\
\hline $2.00-2.30 \mathrm{pm}$. & Chairperson \\
\hline & Open session and policy suggestions \\
\hline $2.30-3.30 \mathrm{pm}$. & Post training KAP of RTI Case Management \\
\hline $3.30-4.00 \mathrm{pm}$. & \\
\hline
\end{tabular}


Appendix D

Distribution of patients according to their type of problems who were served by SIFPSA lady doctor during Nov. 1995 to Oct. 1997 (88 clinic days)

\begin{tabular}{|c|c|c|c|c|}
\hline Groups & Problems & Numbers & Percent* & Percent** \\
\hline $\begin{array}{l}\text { Gynaec } N=637 \\
(22.2 \%)\end{array}$ & $\begin{array}{l}\text { Infertility: Primary } \\
\text { Irregular bleeding } \\
\text { Scanty bleeding } \\
\text { Excessive bleeding } \\
\text { Frequent periods } \\
\text { Ameanorrhoea } \\
\text { Dysmenorrhoea } \\
\text { Menopausal complaints } \\
\text { Prolapse } \\
\text { UTI } \\
\text { Itching vulva } \\
\text { Bad cervix (erosion, chronic and acute cervitis) } \\
\text { Vaginitis }\end{array}$ & $\begin{array}{r}132 \\
52 \\
146 \\
47 \\
28 \\
25 \\
91 \\
15 \\
21 \\
25 \\
43 \\
5 \\
4 \\
3\end{array}$ & $\begin{array}{l}4.6 \\
1.8 \\
5.1 \\
1.6 \\
1.0 \\
0.9 \\
3.2 \\
0.5 \\
0.7 \\
0.9 \\
1.5 \\
0.2 \\
0.1 \\
0.1\end{array}$ & $\begin{array}{r}16.3 \\
6.4 \\
18.0 \\
5.8 \\
3.4 \\
3.1 \\
11.2 \\
1.8 \\
2.6 \\
3.1 \\
5.3 \\
0.6 \\
0.5 \\
0.4\end{array}$ \\
\hline $\begin{array}{l}\text { Obstetrics } \\
\mathrm{N}=1722(59.9 \%)\end{array}$ & $\begin{array}{l}\text { Normal pregnancy } \\
\text { Pregnancy with pain/other general problems } \\
\text { Pregnancy with anaemia/high risk factors } \\
\text { Preg. withlabour pain/loss of foetal movement } \\
\text { Lactational amaenorrhoea/suspected pregnancy } \\
\text { PNC with problems } \\
\text { Abortion/MTP services } \\
\text { Incomplete abortion }\end{array}$ & $\begin{array}{r}702 \\
300 \\
200 \\
62 \\
183 \\
53 \\
161 \\
61\end{array}$ & $\begin{array}{r}24.4 \\
10.4 \\
7.0 \\
2.2 \\
6.4 \\
1.8 \\
5.6 \\
2.1\end{array}$ & $\begin{array}{r}40.8 \\
17.4 \\
11.6 \\
3.6 \\
10.6 \\
3.1 \\
9.3 \\
3.6\end{array}$ \\
\hline $\begin{array}{l}\text { Reproductive } \\
\text { tract infection } \\
\mathrm{N}=401(14.0 \%)\end{array}$ & $\begin{array}{l}\text { Vaginal discharge } \\
\text { Pelvic Inflammatory Disease } \\
\text { Leucorrhoea } \\
\text { Chronic or acute cervicitis } \\
\text { Lower abdominal pain } \\
\text { Trichoma } \\
\text { Trichomoniasis } \\
\text { Candidiasis }\end{array}$ & $\begin{array}{r}10 \\
179 \\
175 \\
10 \\
12 \\
3 \\
9 \\
3\end{array}$ & $\begin{array}{l}0.3 \\
6.2 \\
6.1 \\
0.3 \\
0.4 \\
0.1 \\
0.3 \\
0.1\end{array}$ & $\begin{array}{r}4.4 \\
79.2 \\
21.6 \\
4.4 \\
5.3 \\
1.3 \\
4.0 \\
1.3\end{array}$ \\
\hline $\begin{array}{l}\text { Family planning } \\
\mathrm{N}=59(2.1 \%)\end{array}$ & $\begin{array}{l}\text { FP advise or service } \\
\text { Follow-up of ligation }\end{array}$ & $\begin{array}{r}6 \\
53\end{array}$ & $\begin{array}{l}0.2 \\
1.8\end{array}$ & $\begin{array}{l}10.2 \\
89.8\end{array}$ \\
\hline \multirow[t]{2}{*}{$\begin{array}{l}\text { Other diseases } \\
\mathrm{N}=296(10.3 \%)\end{array}$} & $\begin{array}{l}\text { Abdominal pain } \\
\text { Chronic Amoebiasis } \\
\text { General health problems (fever, weakness, backache, } \\
\text { loss of appetite, acidity) }\end{array}$ & $\begin{array}{r}79 \\
89 \\
128\end{array}$ & $\begin{array}{l}2.7 \\
3.1 \\
4.5\end{array}$ & $\begin{array}{l}26.7 \\
30.1 \\
43.2\end{array}$ \\
\hline & Total number of cases & 2873 & 2873 & \\
\hline
\end{tabular}

* Based on all types of patients served by lady doctor.

**Taking category number of patients in respective broad categories i.e., RTI, gynaec, obstetric, RTI, FP and other cases as the base. 